\title{
Evaluation of some tumor markers, acute phase proteins, sialic acid and lipid bound sialic acid before and after chemotherapy in patients with stomach cancer
}

\author{
Aysegul Cebi ${ }^{1}$, Handan $\mathrm{Mert}^{2}$, Nihat Mert ${ }^{2}$
}

\begin{abstract}
Objective: It was aimed to compare the some tumor markers, acute phase proteins, sialic acid and lipid bound sialic acid levels in patients with stomach cancer before and after chemotherapy to the healthy controls

Material and Methods: Forthy-eight patients with stomach adenocarcinoma and 20 healthy controls, totally 68 subjects were used. Blood samples were taken from all patients before and after chemotherapy and controls to analyze the levels of tumor markers (CA 125, CA 15-3, CA 19-9, CEA), acute phase proteins (CRP and fibrinogen) and SA (sialic acid), LSA (lipid bound sialic acid).

Results: Before chemotherapy the serum levels of CA 125, CA 15-3, CA 19-9, CEA SA, LSA, CRP and fibrinogen $(107.30 \mathrm{U} / \mathrm{ml}, 65.74 \mathrm{U} / \mathrm{ml}, 295.86 \mathrm{U} / \mathrm{ml}, 108.57 \mathrm{ng} / \mathrm{ml}, 199.60 \mathrm{mg} / \mathrm{dl}, 41.89 \mathrm{mg} / \mathrm{dl}, 86.03 \mathrm{mg} / \mathrm{l}$ and $469.42 \mathrm{mg} / \mathrm{dl}$ ) were higher than after chemotherapy group $(36.46 \mathrm{U} / \mathrm{ml}, 34.00 \mathrm{U} / \mathrm{ml}, 100.18 \mathrm{U} / \mathrm{ml}, 20.20 \mathrm{ng} / \mathrm{ml}$, $87.67 \mathrm{mg} / \mathrm{dl}, 31.06 \mathrm{mg} / \mathrm{dl}, 57.04 \mathrm{mg} / \mathrm{l}$ and $379.04 \mathrm{mg} / \mathrm{dl})$ and the controls $(8.64 \mathrm{U} / \mathrm{ml}, 21.65 \mathrm{U} / \mathrm{ml}, 21.52 \mathrm{U} / \mathrm{ml}$, $2.77 \mathrm{ng} / \mathrm{ml}, 73.75 \mathrm{mg} / \mathrm{dl}, 27.47 \mathrm{mg} / \mathrm{dl}, 2.37 \mathrm{mg} / 1,303.5 \mathrm{mg} / \mathrm{dl})$.

Conclusion: The serum levels of SA and LSA may be considered the indicators of poor/good prognosis of stomach cancer. CRP and fibrinogen are suggested as available biomarkers for diagnosis and prognosis in patients with stomach cancer.
\end{abstract}

Key words: Acute phase proteins, sialic acid, lipid bound sialic acid, stomach cancer, tumor markers

\section{Introduction}

The prevalence of stomach cancer has shown differences among the countries. It is still in the second rank at the cancer deaths in the world despite the clear decrease in its prevalence. The stomach cancer is the most commonly case in Van and its vicinity (1). Because the stomach cancer is a insidious disease, it is difficult to understand its etiology, there are many studies on the biomarkers or tumor markers to support the diagnosis. Tumor markers which have different characteristics such as glycoprotein and glycolipid show specific features for many organ cancers. They help to diagnose the cancer and also help to estimate the good and poor prognosis of the cancer patients. The origin of marker can even be the ectopic hormon synthesis, oncofetal antigens and the metabolic products of neoplastic cell or the answer of the patient to the tumor development (2). The qualitative or quantitative chemical, molecular biological or immunologic methods can be used for the diagnosis of cancer.
They are valuable than the other diagnostic tools for determining the early stage of tumor. Today, it was proved that the tumor markers like CEA, CA 15-3, CA 125, CA 19-9 have important places in clinical use for some cancers (3).

The sialic acid, a monosaccharide with negative charge of 9 carbons, has many functions such as protecting the structures of cell membranes and glycoproteins, cell to cell interactions, membrane transport, binding molecule in membrane receptors, effects in the blood glycoprotein structure, regulating the permeability in basal membrane of glomerules (4). The abnormal glycosylation process in tumor cells increases the sialic acid level in the surface of malignant and trasformed cells by contributing to the biosynthesis of carbohydrate structure. Some studies showed that cell form, cell stickness and the growth rate affect the sialic acid content of the cell (5). The ratio of carbohydrate synthesis in the growing cells was found relatively high when compared with the ungrown cell (6).

\footnotetext{
Received:03-09-2015, Accepted 29-09-2015, Available Online 15-01-2016

1 Giresun University, School of Medicine, Dept. of Molecular Biology, Giresun, Turkey

2 Yuzuncu Y University, School of Science Dept. of Chemistry, Van Turkey

*Corresponding Author: Aysegul Cebi E-mail: cebiaysegul@hotmail.com
} 
Acute phase proteins are mostly synthesized by hepatocytes in response to pro-inflammatory cytokines to tissue injury and infections. CRP, fibrinogen, haptoglobin, complement factors, ceruloplasmin, ferritin and serum amiloid A can be taken into account as acute phase proteins (7). CRP is produced by liver within 6 hours of an acute inflammation by the direct stimulation of IL-6. It is a pentraxin protein which has $\mathrm{Ca}$-dependent ligand binding. The relation between IL-6 and CRP were shown in various types of cancer. CRP was important in poor cancer prognosis and metastasis $(8,9)$. Some researches were found that fibrinogen, blood clotting factor, can be a good tumor marker in pancreas, esophagus and stomach cancers (10-12).

In this study, it was aimed (i) to compare the tumor markers, acute phase proteins, sialic acid and lipid bound sialic acid levels of the stomach cancer patients before and after chemotherapy; (ii) to evaluate the importance of sialic acid and lipid bound sialic acid for gastric cancer.

\section{Material and Methods}

\section{Patients and Blood Sampling}

Totally 48 patients ( 33 male and 15 female, age of 45-76) diagnosed as stomach cancer in Yuzuncu Y1l University Faculty of Medicine Oncology Clinic and 20 healthy controls (12 male and 8 female, age of 35-64) were chosen to the study. Stomach adenocarcinoma was diagnosed by endoscopic biopsy in all the patients. The cancer were ranked into stages by lung graphy, abdominal computed tomography, biochemistry, hemogram and if needed magnetic resonans. The patients who are in localised stages were excluded from the study because they were chosen for surgical treatment. The advanced local and metastatic cancer patients were chosen to study because they were the candidates for systematic chemotherapy. Blood were taken before starting treatment and then cisplatin and 5-flourouracil based chemotherapy was started orally or intravenously. After it was repeated 3-4 times in two or three weeks, according to the chemotherapy protocols.

Cisplatin-5 FUFA (5Flourouracil-Folinic acid) was given biweekly or cisplatin-UFT (uracil tegafur) was given once in 21 days. Responses of all patients to this chemotherapy were investigated clinically and radiological after 3-4 cures. Chemotherapy protocol is listed in table 1- 2 .

Blood samples were taken from all patients into the non-anticoagulant and sodium citrate tubes after the chemotherapy. They were centrifuged for 10 minutes in $2500 \mathrm{rpm}$, sera and plasma were separated.

Measurement of SA, LSA, Tumor Markers and Acute Phase Proteins
The levels of serum SA $(13,14)$ and $\operatorname{LSA}(15,16)$ were determined spectrophotometrically. The LSA level were calculated by using calibration curve (1317). The serum CA 125, CA 15-3, CA 19-9, CEA tumor marker levels were determined in autoanalyzer with chemiluminescent immunoassay method by using commercial kits (Immulite 2000 DPC, LosAngeles, USA) (18). The serum CRP measurement was done by nefelometer (Dade Behring, Model BN II) by using hsCRP kit $(19,20)$ Plasma fibrinogen levels were determined by Clauss Clotting Method with STA Compact (21).

Statistical analysis: Statistical analyses were performed using SPSS (SPSS Inc, Chicago IL, USA) version 17.0. The statistical analyses were done by Wilcox Test and Mann Whitney-U Test.

Results

The levels of tumor markers (CA 125, CA 15-3, CA 19-9 and CEA), SA, LSA and the acute phase proteins (CRP and fibrinogen) of the stomach cancer patients and the controls before and after chemotherapy are shown in Table 3.

The levels of CA 125, CA 15-3, CA 19-9, CEA, SA, LSA, CRP and fibrinogen were found higher than the controls. They were declined after the chemotherapy but still high. As seen in table 3, there were statistical importances among the groups.

While serum level of CA 125 was found as 107.30 U/ml before chemotherapy and diminished to $36.46 \mathrm{U} / \mathrm{ml}$ after chemotherapy. The serum level of CA 125 of the control group was found as $8.64 \mathrm{U} / \mathrm{ml}$.

The serum levels of CA 15-3 before chemotherapy in stomach cancer patients were higher $(65.74-21.65 \mathrm{U} / \mathrm{ml})$ than that of both the controls and after chemotherapy.

While the serum levels of CA 19-9 in stomach cancer patients were found higher compared than that of the controls $(295.86-21.52 \mathrm{U} / \mathrm{ml} ; \mathrm{p}<0.05)$, this value was dropped to $100.18 \mathrm{U} / \mathrm{ml}$ after chemotherapy and found as statistically important compared to before chemotherapy $(\mathrm{p}<0.05)$.

Before and after chemotherapy serum levels of CEA were found statistically high $\mathrm{p}<0.001$ and $\mathrm{p}<0.01$, respectively when compared to the controls. After chemotherapy serum levels of CEA (20.20 $\mathrm{ng} / \mathrm{ml})$ were found statistically low $(\mathrm{p}<0.01)$, when compared to before chemotherapy $(108.57 \mathrm{ng} / \mathrm{ml})$.

It was determined that the serum levels of SA were higher significantly $(199.60 \mathrm{mg} / \mathrm{dl}-73.75 \mathrm{mg} / \mathrm{dl}$; $\mathrm{p}<0.001)$ before chemotherapy when compared to the controls. While the level of SA was statistically lower after chemotherapy $(87.67 \mathrm{mg} / \mathrm{dl})$ compared to before chemotherapy groups. 
Table 1. Chemotherapy protocol

\begin{tabular}{|c|c|c|c|}
\hline & $\begin{array}{c}\text { Total } \\
\text { dosage }\end{array}$ & $\begin{array}{l}\text { Application } \\
\text { days }\end{array}$ & Application method \\
\hline Cisplatin $30 \mathrm{mg} / \mathrm{m}^{2}$ & $*$ & D1-2 & Infusion for two hours in $1000 \mathrm{ml}$ isotonic. \\
\hline Folinic acid $20-35 \mathrm{mg} / \mathrm{m}^{2}$ & $*$ & D1-2 & Infusion for 30 minutes in $150 \mathrm{ml}$ isotonic \\
\hline $\begin{array}{l}\text { Flourouracil } 400 \mathrm{mg} / \mathrm{m} \text { IV } \\
\text { bolus }+10001500 \mathrm{mg} / \mathrm{m}^{2} \text { IV infusion }\end{array}$ & * & D1-2 & $\begin{array}{l}\text { Dosage which should be applied after bolus } \\
\text { dosage infused for } 3-4 \text { hours in } 500 \mathrm{ml} \% 5 \mathrm{D} \\
\text { (Dextrose) }\end{array}$ \\
\hline
\end{tabular}

* Body mass index of patients were calculated according to their length and weight ratio. The drug dosage was given as mg per square meter.

1-Cisplatin $30 \mathrm{mg} / \mathrm{m}^{2}$; two days intervals

Folinic acid $30 \mathrm{mg} / \mathrm{m}^{2}$; two days intervals

$5 \mathrm{FU} 1000 \mathrm{mg} / \mathrm{m}^{2}$; two days intervals as biweekly

Table 2. Chemotherapy protocol

\begin{tabular}{|c|c|c|c|}
\hline & $\begin{array}{l}\text { Total } \\
\text { dosage }\end{array}$ & $\begin{array}{l}\text { Application } \\
\text { days }\end{array}$ & Application method \\
\hline Cisplatin 60-75mg/m2 & $*$ & D1-2 & Infusion for two hours in $1000 \mathrm{ml}$ isotonic \\
\hline UFT tablet $300 \mathrm{mg} / \mathrm{m} 2$ & $*$ & D1-14 & It was taken in the morning and evening after meal. \\
\hline
\end{tabular}

Table 3.Tumor markers, SA, LSA and the acute phase protein levels in the control group and the stomach cancer patients

\begin{tabular}{|c|c|c|c|c|c|c|}
\hline & $\begin{array}{c}\text { Control } \\
(n=20)\end{array}$ & $\begin{array}{c}\text { Before } \\
\text { Chemotherapy } \\
(n=48)\end{array}$ & $\begin{array}{c}\text { After } \\
\text { Chemotherapy } \\
(\mathrm{n}=\mathbf{2 4})\end{array}$ & & & \\
\hline & $\mathbf{X} \pm \mathrm{SD}$ & $\mathbf{X} \pm \mathbf{S D}$ & $\mathbf{X} \pm \mathbf{S D}$ & $\mathbf{A}$ & B & C \\
\hline CA $125(\mathrm{U} / \mathrm{ml})$ & $8.64 \pm 4.45$ & $107.30 \pm 140.11$ & $36.46 \pm 51.45$ & $\mathrm{p}<0.001$ & $\mathrm{p}<0.05$ & $\mathrm{p}<0.01$ \\
\hline CA $15-3(\mathrm{U} / \mathrm{ml})$ & $21.65 \pm 11.96$ & $65.74 \pm 76.47$ & $34.00 \pm 43.05$ & $\mathrm{p}<0.01$ & $\mathrm{p}=0.494$ & $\mathrm{p}<0.01$ \\
\hline CA $19-9(\mathrm{U} / \mathrm{ml})$ & $21.52 \pm 7.78$ & $295.86 \pm 382.85$ & $100.18 \pm 278.05$ & $\mathrm{p}<0.05$ & $\mathrm{p}=0.054$ & $\mathrm{p}<0.05$ \\
\hline CEA (ng/ml) & $2.77 \pm 1.60$ & $108.57 \pm 162.21$ & $20.20 \pm 42.22$ & $\mathrm{p}<0.001$ & $\mathrm{p}<0.01$ & $\mathrm{p}<0.01$ \\
\hline SA (mg/dl) & $73.75 \pm 7.57$ & $199.60 \pm 7.64$ & $87.67 \pm 13.19$ & $\mathrm{p}<0.001$ & $\mathrm{p}<0.001$ & $\mathrm{p}<0.001$ \\
\hline LSA (mg/dl) & $27.47 \pm 2.91$ & $41.89 \pm 5.98$ & $31.06 \pm 3.64$ & $\mathrm{p}<0.001$ & $\mathrm{p}<0.01$ & $\mathrm{p}<0.001$ \\
\hline CRP (mg/l) & $2.37 \pm 1.45$ & $86.03 \pm 2.16$ & $57.04 \pm 75.45$ & $\mathrm{p}<0.001$ & $\mathrm{p}<0.001$ & $\mathrm{p}=0.054$ \\
\hline Fibrinogen (mg/dl) & $303.50 \pm 58.22$ & $469.42 \pm 131.10$ & $379.04 \pm 114.39$ & $\mathrm{p}<0.001$ & $\mathrm{p}<0.01$ & $\mathrm{p}<0.01$ \\
\hline
\end{tabular}

A. Mann Whitney U Test results between the control and before chemotherapy group values

B. Mann Whitney U Test results between the control and after chemotherapy group values

C. Wilcox Test results between the before and after chemotherapy groups

The serum levels of LSA were elevated significantly (41.89 $\mathrm{mg} / \mathrm{dl}-27.47 \mathrm{mg} / \mathrm{dl})$ before chemotherapy when compared after chemotherapy and control group. The level of LSA was significantly reduced after chemotherapy $(31.06 \mathrm{mg} / \mathrm{dl})$ when compared to before chemotherapy groups and the controls $(\mathrm{p}<0.01)$.

The level of CRP was higher before chemotherapy $(86.03 \mathrm{mg} / \mathrm{l}-2.37 \mathrm{mg} / \mathrm{l} ; \quad \mathrm{p}<0.001)$ compared to the controls. Despite that it decreased down to $57.04 \mathrm{mg} / \mathrm{l}$ after chemotherapy, it still remained statistically higher when compare to the controls. The levels of fibrinogen were $469.42 \mathrm{mg} / \mathrm{dl}$ and $379.04 \mathrm{mg} / \mathrm{dl}$ before and after chemotherapy. Significantly differences were found between the groups.

Medical Science and Discovery, 2016; 3(1): 22-7

\section{Discussion}

Cancer is one of the severe disease cause death and mostly diagnosed at the latest stage or during metastasis. Therefore, early diagnosis is an important factor for the treatment and prognosis. CEA ve CA 19-9 and CA 125 can be used for the prediction of the stage and prognosis of the cancer $(22,23)$.

Yamamoto et al. (24) stated that CEA diagnosed and predicted the peritonal spread better than CA 125 ve CA 19-9 in stomach cancers which show peritonal spread. Takahashi (25) emphasized that CEA and/or CA 19-9 is the important biomarkers for observing the recurrence probability of stomach cancer after the operation. Webb et al. (26) stated that CEA $\geqslant 5 \mathrm{mg} / \mathrm{l}$ and $\mathrm{CA} 125 \geqslant 350 \mathrm{U} / 1$ reflect the poor prognosis in 
advanced stomach cancer patients before chemotherapy.

In the presented study, four different tumor markers (CA 125, CA 15-3, CA 19-9 and CEA) were measured in pre and post-treatment at stomach cancer patients and compared with the healthy controls. These tumor marker levels were determined higher before chemotherapy in stomach cancer patients. It was still found higher even there was a decrease in ongoing post-treatment level while the levels of the tumor markers were decreased following the chemotherapy. It can indicate the effectiveness of the treatment, positive improvement in prognosis and the extention of the patients' life time .

The tumor cells have got different surface charasteristics compared to the normal cells which were partly resulted from sialoglycoconjugate. The behaviors and metastatic characteristics of the cells are affected by them. The sialic acid level in malign cell surface is related with metastasis (5). Many researchers determined that total and lipid bounded sialic acid levels increased in different cancer types $(27,28)$. It is known that the sialic acid is necessary for cell adhesion and carries out the electrostatic impulse in thrombocyte, cancer cells and erythrocytes via the negative charge (29).

The high level of serum SA and LSA can originate from increased synthesis or sialic acid release which is found on the cell surface glycoconjugate (30). Furthermore, it was suggested that the sialic acid concealed the tumor cells or tumor specific antigens from the immunological attack, and protected the invasion and metastatic characters of malignant cells (31).

Total serum sialic acid levels increases in stomach cancer patients (32). A positive correlation was found between stage of cancer, metastasis grade and sialic acid level. The high serum sialic acid level shows poor prognosis (28,33). While Krasnodebski (34) put negative opinion for the biomarker probability of sialic acid level because of its $55.2 \%$ sensitivity, the increased serum SA level in metastasis supports the metastatic cell existance.

As it can be seen in this study that SA and LSA levels increased in stomach cancer cases and decreased after chemotherapy. The increased levels of SA and LSA in stomach cancer were compatible with the previous literatures. The increased serum levels of SA and LSA in malignant cases must be carefully evaluated owing to the levels of them can be rised in some other diseases. Therefore, SA and LSA should be interpreted with the other markers and acute phase proteins. However, Raval et al. (35) reported that high level of SA is a sign of weak or poor prognosis of oral cavity cancer.
In other study, CRP and cytokine levels were investigated in stomach cancer patients. A correlation was found between poor prognosis and systemic inflammation. Furthermore, CRP was also related with the decrease of the patients' life span (36). Wu et al. (37) indicated that there was a moderate correlation between CRP and increased cytokine levels in stomach cancer.

Fukata et al. (38) determined that CRP level in liver cancer patients with stomach metastasis and also reported that the level of CRP was decreased following the gastrectomy. Tavaris et al. (39) evaluated the levels of CRP, transferrin, $\alpha-2$ macroglobulin, ceruloplasmin, $\alpha-1$ acide glycoprotein, retinol binding protein and prealbumin in 153 stomach cancer patients before surgical operation. The level of CRP was clearly higher in patients than the controls but any differences were not found in other parameters (39). It was concidered that CRP was more sensitive than the other acute phase proteins in cancer patients.

In this study, levels of CRP were found as 2.37 $86.03-57.04 \mathrm{mg} / \mathrm{l}$ in all three groups (control, pretreatment and post-treatment), respectively. The main reason of the high CRP level in stomach cancer patients is the stimulation of CRP synthesis by cytokine response to the cancer formation. The major inducer of CRP synthesis is IL-6. Likewise, Iijima et al. (40) stated that the high level of IL- 6 was found in stomach cancer patients. In addition, CRP is the fastest responder of the acute phase proteins during the infection.

The high plasma fibrinogen level was found usually in malignant diseases. However, Di Micco et al. (41) showed that the fibrinogen level increased in 11 nonmetastatic stomach cancer. Some studies have been done to explain the relationship between the plasma fibrinogen levels and tumor size, invasion depth and metastasis (42). While the hyperfibrinogenemia was related with cancer progression and metastasis, the low level of fibrinogen was a sign of weak metastasis (43). Yamashita et al. (12) evaluated the CEA, CRP and fibrinogen levels in the 649 operated patients with stomach cancer. They proposed that hyperfibrinogenemia could provide favorable circumstances for cancer cells to metastasize via the lymphatic system. The plasma level of preoperative fibrinogen could be a useful predictor of lymphatic metastasis in patients with intestinal-type gastric cancer.

Yamamura et al. (44) observed that fibrinogen activity was decreased in stomach cancer patients after total stomach resection. Brajerzki et al. (45) measured the plasma level of fibrinogen in patients with stomach cancer and ulcer. They could not determine any increase of fibrinogen in patients with ulcer but there was a high increase in $67 \%$ of cancer patients. Some hematological parameters such as fibrinogen, 
thrombocyte, hematocrit were investigated in 63 cancer patients, and all parameters in cancer patients were higher than the controls (46).

In this study, the fibrinogen level showed significant increase in pre-treatment group compared to the other two groups. The values of fibrinogen levels were at normal margins because the laboratory measurement intervals were $300-400 \mathrm{mg} / \mathrm{dl}$. Our results with regard to fibrinogen level were compatible with investigated literatures. Likewise, Wang et al. (47) recommended that fibrinogen was related with cancer diagnose and prognose like the other parameters.

\section{Conclusion}

As a consequence, significant increases were determined in the serum levels of CA 125, CA 15-3, CA 19-9, CEA, SA, LSA, CRP and fibrinogen of patients with stomach cancer. It is strongly emphasized that SA and LSA may be considered as tumor markers, and also acute phase proteins such as CRP and fibrinogen should be used for diagnosis and prognosis in patients with stomach cancer before and after chemotherapy.

Acknowledgements: This research was supported by the YYU Directory of Scientific Research Project as 2006-SBE-D100 Project number. The authors declare that there is no conflict of interest with this work.

Conflict of Interest: The authors declare no potential conflicts of interest with respect to the research, authorship, and/or publication of this article.

\section{References}

1. Turkdogan MK, Akman N, Tuncer I, et al. Epidemiological aspects of endemic upper gastrointestinal cancers in Eastern Turkey. Hepato-Gastroenterology. 2005 52: $496-500$

2. Hanna EYN, Papay FA, Gupa MK. Head Neck. 1990; 12: $50-59$

3. Perkins GL, Slater ED, Sanders GK, Prichard JG. Serum Tumor Markers. Am Fam Physician. 2003; 68:1075-1082.

4. Pönniö M, Alho H, Nikkari ST, Olsson U, Rydberg U, Sillanuaukee P. Serum sialic acid in a random sample of the general population. Clin Chem. 1999; 45: 1842-1849.

5. Yogeeswaran G. Cell surface glycolipids and glycoproteins in malignant transformation. Adv Cancer Res. 1983; 38: 289-350

6. Kaplan J, Moskowitz M. Studies on the turnover of plasma membranes in cultured mammalina cells. I. Rates of synthesis and degradation of plasma membrane proteins and carbohydrates. Biochim Biophys Acta. 1975; 389: 290305

7. Dinarello CA. The acute phase response, Cecil Textbook of Medicine. 1992; 286: 1571-1573.
8. Ljunberg B, Grankvist K, Rasmuson T. Serum Interleukin -6 in relation to acute-phase reactants and survival in patients with renal cell carcinoma. Eur J Cancer. 1997; 33: 1794-1798.

9. Nikiteas N, Tzanakis N, Gazouli M et al. Serum IL-6, TNF-? and CRP levels in colorectal cancer patients: Prognostic implications. World J Gastroenterol. 2005; 11: $1639-1643$

10. Bloomston M, Zhou JX, Rosemurgy AS, et al. Fibrinogen ? overexpression in pancreatic cancer identified by largescale proteomic analysis of serum samples. Cancer Res. 2006; 66: 2592-2599.

11. Takeuchi H, Ikeuchi S, Kitagawa Y, et al. Pretreatment plasma fibrinogen level correlates with tumor progression and metastasis in patients with squamous cell carcinoma of the esophagus. J Gastr Hepatol. 2006; 10:1440-1446.

12. Yamashita H, Kitayama J, Nagawa H. Hyperfibrinogenemia is a useful predictor for lymphatic metastasis in human gastric cancer. Jpn J Clin Oncol. 2005; 35: 595-600

13. Katapodis N, Hirshaut Y, Geller N, Stock CC. Lipid associated sialic acid test for the detection of human cancer. Cancer Res. 1982; 42: 5270-5275.

14. Sydow GA. Simplified quick method for determination of sialic acid in serum. Biomed Biochim Acta. 1985; 44: 1721-1723

15. Gottschalk A, Drzenick R. Neuraminidase as a structural analysis: Glycoproteins, their composition structure and function, 2nd Ed, Elsevier, Publishing Co, Amsterdam. $1972 ; 402-447$

16. Whitehouse MV, Lilliken F. Isolation and determination of neuraminic (sialic) acid, method of the biochemical analysis, In: D Glick, Editor, Vol XIII, Interscience Publishers NewYork. 1963; 199-220.

17. Dnistrian AM, Schwartz MK, Katopodis N, Fracchia AA, Stock CC. Serum lipid-bound sialic acid as a marker in breast cancer. Cancer. 1982; 50: 1815-1819.

18. Nisellbaum JS, Simith CA, Scwartz D, Scwartz MK. Comparison of Roch EIA, Hybritech EIA and Abbott EIA methods for measuring carcinoembrionic antigen. Clin Chem. 1988; 34: 761-764

19. Baudner S, Bienvenu J, Blirup-Jensen S. The certification of a matrix reference material for immunochemical measurement of 14 human serum proteins. CRM 470. Brussels: Community Bureau of Reference, Commission of the European Communities. BCR Information, Reference Materials. report EUR 15243 EN (ISSN 1018-5593). 1993; $1-172$.

20. Whicher JT, Ritchie RF, Johnson AM, et al. New international reference preparation for proteins in human serums (RPPHS). Clin Chem. 1994; 40: 934-938.

21. Von Clauss A. Gerinnungphysiologische Schnellmethode zur bestimmung des fibrinogen. Acta Haematol. 1957; 17 : $237-46$.

22. Mihmanlı M, Dilege E, Demir U, Coşkun H, Eroglu T, Uysalol MD. The use of tumor markers as predictors of prognosis in gastric cancer. Hepatogastroenterol. 2004; 51: 1544-1547. 
23. Yamao T, Kai S, Kazami A. Tumor markers CEA, CA 199 and CA 125 in monitoring of systemic chemotherapy in patients with advanced gastric cancer. Jpn J Clin Oncol. 1999; 29: 525-526.

24. Yamamoto M, Baba H, Kakeji Y, et al. Prognostic significance of tumor markers in peritoneal lavage in advanced gastric cancer. Oncology. 2004; 67: 19-26.

25. Takahashi Y. Gastrointestinal cancer. Gan To Kagaku Ryoho. 2004; 31: 1275-1279.

26. Webb A, Scott-Mackie P, Cunningham D. The prognostic value of CEA, beta HCG, AFP, CA 125, CA 19-9 and Cerb B-2, beta HCG immunohistochemistry in advanced colorectal cancer. Ann Oncol. 1995; 6: 581-587.

27. Dwivedi C, Dixit M, Hardy RE. Plasma lipid-bound sialic acid alterations in neoplastic diseases. Experientia. 1990; 46: $91-94$

28. Shamberger RJ. Evaluation of water soluble and lipid soluble sialic acid levels as tumor markers. Anticancer Res. 1986; 6: 717-720

29. Calatroni A, Cordaro V, Salpietro C, Barberi I. Erythrocyte membrane sialic acid in new-born infants. Acta Haematol. 1984; 71: 198-203.

30. Singhal A, Hakomori S. Molecular changes in carbonhydrate antigens associated with cancer. Bioassays. 1990; 12: 223-230.

31. Thomas P. Cell surface sialic acid as a mediator of metastatic potential in colorectal cancer. Cancer J. 1996; 9: $1-6$.

32. Tewarson SL, Mittal VP, Singh M, Gupta GP. Serum sialic acid-an important cancer marker. Indian J Cancer. 1993; 30: 125-131.

33. Shamberger RJ. Serum sialic acid in normal and in cancer patients. J Clin Chem Clin Biochem. 1984; 22: 647-651.

34. Krasnodebski IW. Usefullness of biochemical tumor markers (CEA, CA 19-9, ferritin, and sialic acid) in diagnosis and prognosis of colonic neoplasms. Wiad Lek. 1998; 51, 132-141.

35. Raval GN, Patel DD, Parekh LJ, Patel, JB, Shah MH, Patel PS. Evaluation of serum sialic acid, sialyltransferase and sialoproteins in oral cavity cancer. Oral Dis. 2003; 9: 119 128.
36. Deans DA, Wigmore SJ, Gilmour H. Elevated tumour interleukin-1beta is associated with systemic inflammation: A marker of reduced survival in gastro-oesophageal cancer. Br J Cancer. 2006; 95: 1568-1575.

37. Wu CW, Wang SR, Chao MF, et al. Serum IL-6 levels reflect disease status of gastric cancer. Am J Gastroenterol. 1996; 91: 1417-1422.

38. Fukata T, Fukino S, Hayashi E, Okada K, Tamai N, Nakashima H. A case of G-CSF-producing large cell carcinoma of the lung with gastric metastasis. Kyobu Geka. 2000; 53: 798-803

39. Tsavaris N, Vonorta $\mathrm{K}$, Tsoutsos H, et al. CEA, AFP, CA 19-9 and CA 125 in advanced colorectal cancer (ACC). Int J Biol Markers. 1993; 8: 88-93.

40. Iijima S, Shiba K, Kimura M, Nagai K, Iwai T. Changes of alpha1-acid glycoprotein microheterogeneity in acute inflammation stages analyzed by isoelectric focusing using serum obtained postoperatively. Electroph. 2000; 21: 753759 .

41. Di Micco P, Romano M, Niglio A, et al. Alteration of haemostasis in non-metastatic gastric cancer. Dig Liver Dis. 2001; 33: 546-550

42. Lee JH, Ryu KW, Kim S, Bae JM. Preoperative plasma fibrinogen levels in gastric cancer patients correlate with extent of tumor. Hepatogastroenterol. 2004; 51: 18601863.

43. Palumbo JS, Kombrinck KV, Drew AF, et al. Fibrinogen is an important determinant of the metastatic potential of circulating tumor cells. Blood. 2000; 96: 3302-3309.

44. Yamamura T. Hematological disorders in patients with gastric cancer. Nippon Geka Gakkai Nasshi. 1984; 85: 675685 .

45. Brajerski W, Sikorska K, Bisztyga A, Ilenda M. Blood fibrinogen level in peptic ulcer and gastric carcinoma. Pol Med Sci Hist Bull. 1975; 15: 557-560.

46. Wu S, Zheng D, Lin Q. Clinical study on hemorrhagic changes for metastatic state of gastric cancer and its relationship with syndrome-type in traditional Chinese medicine. Zhongguo Zhong. 2000; 20: 583-585

47. Wang KJ, Wang RT, Zhang JZ. Identification of tumor markers using two dimensional electrophoresis in gastric carcinoma. World J Gastroenterol. 2004; 10: 2179-2183.

Copyright (C) 2014 The Author(s); This is an open-access article distributed under the terms of the Creative Commons Attribution License (http://creativecommons.org/licenses/by/4.0), which permits unrestricted use, distribution, and reproduction in any medium, provided the original work is properly cited. All Rights reserved by international journal of Medical Science and Discovery. 